\title{
APLIKASI TEKNOLOGI TEPAT GUNA PEMISAH KULIT ARI KEDELAI UNTUK UMKM PENGOLAHAN TEMPE DI KECAMATAN SUKAMULIA KABUPATEN LOMBOK TIMUR
}

\author{
Agriananta Fahmi Hidayat ${ }^{*}$, Surya Abdul Muttalib, Asih Priyati \\ Fakultas Teknologi Pangan dan Agroindustri, Universitas Mataram \\ Jalan Majapahit Nomor 62, Mataram 83125 \\ *alamat korespondensi: agriananta.fahmi@unram.ac.id
}

\begin{abstract}
ABSTRAK
Desa Sukamulia, Kecamatan Sukamulia, Kabupaten Lombok Timur dapat dijadikan sebagai suatu wilayah yang cocok dalam pengembangan Technopreuneurship. Sebagian masyarakat desa Sukamulia memiliki aktivitas sosial sebagai guru mengaji dengan usia rata-rata 18-25 tahun. Tingkat pendidikan sebagian masyarakat Desa Sukamulya tersebut adalah SMP dan SMA. Kelompok masyarakat yang tergabung sebagai guru mengaji tersebut memiliki wadah organisasi bernama Remaja Mushola (remus) Nurul Yakin. Remus Nurul Yakin pada saat ini telah memiliki beberapa unit bidang usaha antara lain penjualan pulsa, beras, ayam potong dan tempe. Produksi tempe saat ini merupakan mata pencaharian utama karena permintaan pasarnya yang cukup besar. Pengolahan tempe dilakukan secara tradisional tanpa bantuan mesin pengolahan. Proses pemisahan kulit ari kedelai masih dilakukan dengan cara manual atau ditradisional yang umumnya memiliki kelemahan Yaitu memerlukan waktu yang lebih lama serta tambahan tenaga kerja. Metode tradisional pemisahan kulit ari kedelai dilakukan dengan cara direndam dan diinjak-injak hingga kulit ari terkupas. Metode ini sangat merugikan karena dapat menyebabkan kedelai pecah atau bahkan sampai hancur sehingga hasil tidak bisa maksimal Proses pemisahan kulit ari kedelai ini merupakan salah satu tahapan yang penting dalam proses pembuatan tempe karena mempengaruhi kualitas dari tempe. Kegiatan pengabdian kepada masyarakat ini bertujuan untuk meningkatkan kualitas tempe yang dihasilkan menjadi lebih baik serta efisiensi proses produksi tercapai. Hasil kegiatan pengabdian kepada masayarakat ini adalah bertambahnya pengetahuan pelaku usaha produksi tempe dan hasil produksi yang lebih baik.
\end{abstract}

Kata Kunci: teknologi tepat guna, pemisah kulit ari kedelai, kecamatan sukamulia

\section{PENDAHULUAN}

Desa Sukamulia, Kecamatan Sukamulia, Kabupaten Lombok Timur dapat dijadikan sebagai suatu wilayah yang cocok dalam pengembangan Technopreuneurship. Beberapa pemuda yang tinggal di desa Sukamulia memiliki aktivitas sosial sebagai guru membaca Al-Quran atau 
sebagai guru mengaji dengan usia rata-rata antara 18-25 tahun.Remaja Mushalla pembimbing baca Al-Qurán sebagian besar masih bersekolah dan sebagian lagi putus sekolah ditingkat SMP dan SMA.

Kegiatan pembimbingan di mushalla para guru mengaji tidak mendapatkan upah satu rupiah pun, karena ini merupakan budaya yang sudah berkembang di masyarakat bahwa para pembimbing mengaji di mushalla tidak memperoleh gaji. luran anak-anak yang ikut belajar di mushalla sebesar $\mathrm{Rp} 1.000,00$ perbulan yang digunakan hanya untuk membayar listrik dan kebutuhan alat kebersihan. Guru mengaji tersebut memiliki wadah organisasi bernama Remaja Mushola Nurul Yakin. Remus Nurul Yakin pada saat ini telah memiliki beberapa unit bidang usaha antara lain pulsa, beras, ayam potong dan tempe. Unit usaha ini untuk Komoditas terakhir yakni tempe menjadi bidang usaha utama saat ini karena begitu besar permintaan pasar akan kebutuhan tempe dan tempe merupakan makanan pendamping nasi yang banyak dikonsumsi oleh masyarakat dengan berbagai tingkat ekonomi.

Identifikasi awal menemukan bahwa didalam pengolahan tempe umumnya masih bersifat manual atau metode masih bersifat tradisional. Terutama dalam pemisahan kulit ari kedelai. Menurut Andaluri (2015), Proses pemisahan kulit ari kedelai masih dilakukan dengan cara manual atau tradisional umumnya memiliki kelemahan dalam waktu dan tenaga kerja. Proses pemisahan kulit ari kedelai dilakukan dengan cara direndam dan diinjak-injak hingga kulit ari terkupas. Metode ini sangat merugikan dikarenakan kedelai dapat menjadi pecah atau hancur. Disisi lain hasil pengupasannya terbatas dan sangat bergantung pada kemampuan manusia (Lutfi, dkk, 2010).

Sehingga diperlukan suatu alat yang dapat memisahkan kulit ari kedelai dengan baik, karena kualitas tempe tergantung pada kualitas kedelai yang digunakan. Menentukan alat yang tepat untuk pengupas kulit ari kacang kedelai perlu juga diketahui sifat-sifat dari kacang kedelai itu sendiri. Biji kacang kedelai berkeping dua terbungkus kulit biji. Sifat kacang kedelai ini mampu menyerap air cukup banyak dan dapat menyebabkan beratnya naik menjadi dua kali lipat, dengan sifat biji yang keras dan daya serap air tergantung ketebalan kulit (Annas, 2002).

$$
\text { Potensi pengembangan }
$$
usaha tempe Remaja Mushola Nurul Yakin memerlukan teknologi pemisah kulit ari kedelai sehingga efisiensi waktu dalam proses dapat tercapai yang memungkinkan peningkatan produksi serta pendapatan pengusaha. Selain itu teknologi ini di harapkan dapat membantu produsen meningkatkan kualitas dan kapasitas tempe yang lebih baik. 


\section{METODE KEGIATAN}

Kegiatan pengabdian kepada masyarakat ini telah dilaksanakan pada tanggal 29 September 2018 yang dilaksanakan di Desa Sukamulia, Kecamatan Sukamulia, Kabupaten Lombok Timur. Alat yang digunakan dalam program pengabdian kepada masyarakat ini adalah satu unit mesin pemisah kulit ari kedelai, ember, spanduk, LCD proyektor dan bahan yang digunakan kedelai, ragi, air. Kegiatan pengabdian pada masyarakat ini akan dibagi dalam 4 (empat) kegiatan utama, yaitu:

1. Penyuluhan; akan dilakukan oleh tim pelaksana yang memiliki kompetensi dengan bidang kegiatan pengabdian yang akan dilaksanakan. Kegiatan penyuluhan merupakan bentuk transfer pengetahuan yang disampaikan kepada khalayak sasaran

2. Pelatihan; Kegiatan pelatihan adalah implementasi dari materi pengetahuan yang telah diberikan dalam kegiatan penyuluhan

3. Pendampingan; dalam kegiatan pendampingan, tim pengabdian akan mendampingi kegiatan pengolahan tempe selama waktu 6 minggu

4. Evaluasi; Pelaksanaan evaluasi dilakukan untuk melakukan verifikasi kepada pelaku usaha terhadap terjadinya penyimpangan dalam proses produksi.

\section{HASIL DAN PEMBAHASAN}

Kegiatan
pengabdian kepada masyarakat
dengan tema "Aplikasi Teknologi
Tepat Guna Pemisah Kulit Ari Kedelai
Untuk Industri Rumah Pengolahan
Tempe" dengan melibatkan guru
membaca Al quran di Desa Sukamulia Lombok Timur yang telah memiliki usaha pengolahan tempe. Dengan adanya kegiatan ini diharapkan proses pengolahan menjadi lebih efektif dan produk usaha pengolahan tempe menjadi lebih baik. Kegiatan pelatihan telah dilaksanakan pada tanggal 29 September 2018 di Musholla Nurul Yakin, Desa Sukamulia, Kecamatan Sukamulia, Kabupaten Lombok Timur. Kegiatan diawali dengan acara pembukaan, penyampaian materi/penyuluhan, praktik aplikasi penggunaan mesin pemisah kulit ari kedelai, serta diskusi. Dokumentasi kegiatan dapat dilihat pada Lampiran 1 dan 2.Kegiatan sosialisasi ini secara keseluruhan berjalan dengan baik dan lancar. Antusiasme peserta sangat tinggi dalam mengikuti kegiatan dapat dilihat dengan jumlah peserta yang hadir, keseriusan peserta dalam mendengarkan materi, partisipasi peserta dalam diskusi. Selain itu, peserta juga menceritakan masalah yang mereka hadapi yang berkaitan dengan materi kegiatan seperti hasil pemisahan kulit ari secara manual yaitu diinjak injak yang memiliki banyak kekurangan dan memiliki 
dampak merugikan karena dapat menyebabkan kedelai pecah atau bahkan sampai hancur sehingga hasil tidak bisa maksimal

Pemberian materi kepada peserta selama berlangsungnya kegiatan pengabdian kepada masyarakat adalah sebagai berikut:

- Teknik Pengolahan Tempe

Pada umumnya peserta telah mengetahui bagaimana proses pembuatan tempe akan tetapi dalam kegiatan pengabdian kepada masayarakat ini perlu dijelaskan alur proses pembuatan tempe yang baik dan benar. Sehingga peserta juga mendapatkan ilmu yang luas mengenai bagaimana pembuatan tempe. Mitra diberikan kedelai oleh tim untuk membuat tempe yang sesuai dengan proses yang dipaparkan.

- Cara Kerja dan Penggunaan mesin pemisah kulit ari dan kedelai

Mitra dan Peserta belum pernah menggunakan mesin pemisah kulit ari dan kedelai secara langsung. Dalam materi ini dijelaskan kepada peserta bagaimana sistem kerja dan cara penggunaan mesin pemisah kulit ari dan kedelai. Selain dari penjelasan secara teori peserta langsung dilibatkan dalam praktek penggunaan mesin pemisah kulit ari dan kedelai.

- Metode Pemeliharaan

Mesin pemisah kulit ari dan kedelai akan diberikan kepada mitra sehingga mitra perlu mengetahui bagaimana metode yang tepat dala memelihara mesin pemisah kulit ari dan kedelai. Karena tanpa pemeliharaan mesin pemisah kulit ari dan kedelai yang tepat dapat menyebabkan mesin pemisah kulit ari dan kedelai menjadi cepat rusak.

Tahapan terakhir kegiatan ini adalah diskusi dan evaluasi. Berdasarkan pemantauan selama kegiatan berlansung diketahui peserta pelatihan menguasai cara penggunaan mesin pemisah kulit ari dan kedelai. Para peserta juga memiliki motivasi yang tinggi dalam menggunakan mesin pemisah kulit ari dan kedelai sebagai salah satu proses pembuatan tempe. Peserta juga antusias dalam memperhatikan bagaimana merawat dan memelihara mesin pemisah kulit ari dan kedelai. 


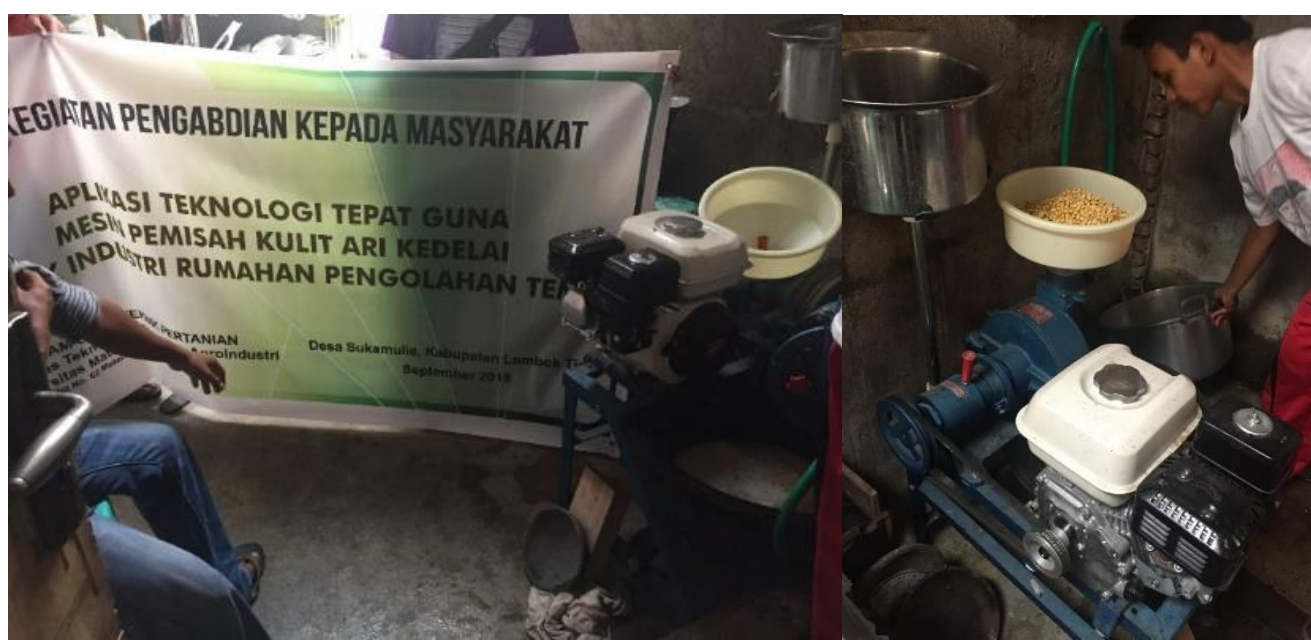

Gambar 1. Mesin Pemisah Kulit Ari Kedelai dan Proses Penggunaan Mesin

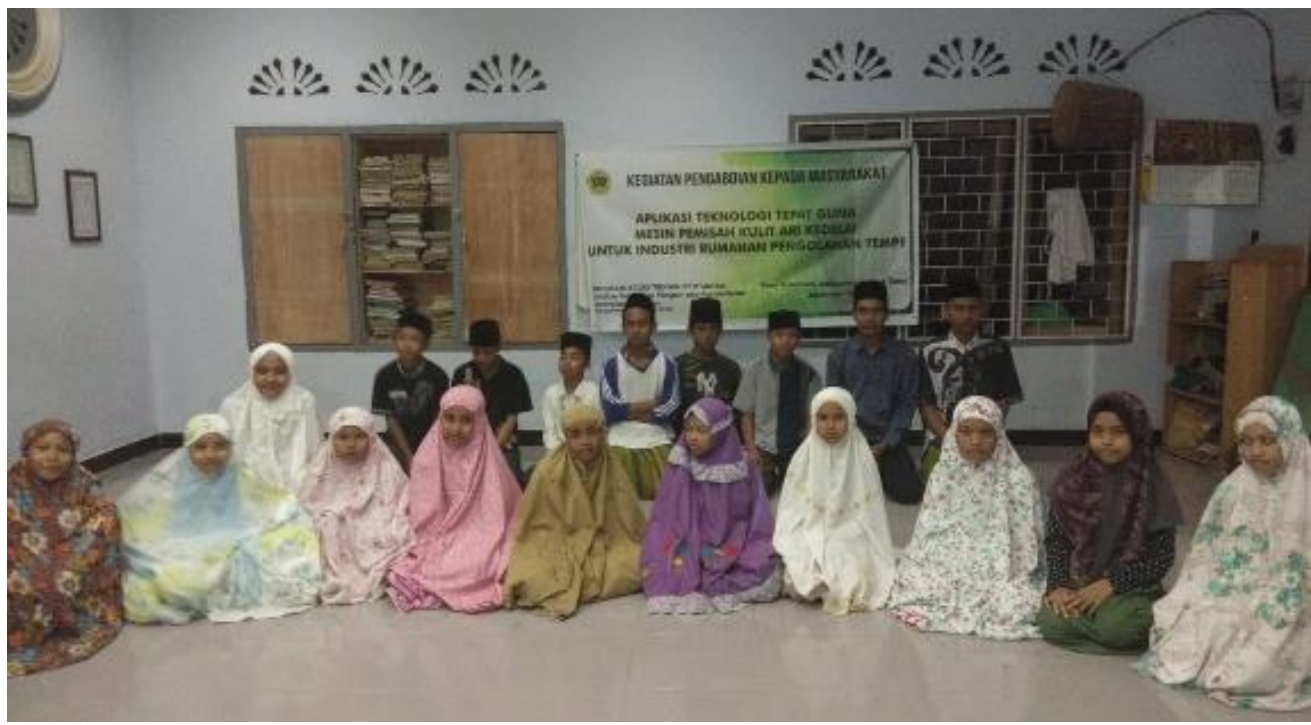

Gambar 2. Penyerahan Alat Sanitasi dan Foto Bersama Peserta Penyuluhan

Setelah tim pengabdian kepada masyarakat menyampaikan materi dilanjutkan dengan kegiatan evaluasi serta sesi tanya jawab mengenai cara kerja dan perawatan mesin pemisah kulit ari dan kedelai. Secara umum kegiatan ini telah berhasil meningkatkan motivasi dan pengetahuan peserta akan mesin pemisah kulit ari dan kedelai. Hal ini dapat dilihat dari antusiasme peserta dalam menyimak materi serta serta adanya saran dan masukan dari peserta terkait pelaksanaan kegiatan penyuluhan.

Faktor Pendukung dan Penghambat Kegiatan Pengabdian Kepada Masyarakat

Keberhasilan pelaksanaan kegiatan pengabdian kepada masyarakat ini didukung oleh beberapa fakor antara lain:

1. Antusiasme dan kesadaran peserta untuk meningkatkan hasil produksi tempe menjadi lebih baik dengan 
menggunakan mesin pemisah kulit ari dan kedelai

2. Mitra sangat bekerjasama dalam melaksanakan kegiatan pengabdian kepada masyarakat ini dan saling membantu untuk menyelesaikan suatu masalah yang dihadapi oleh mitra.

3. Kegiatan ini memberikan keuntungan untuk menghasilkan produk yang lebih bermutu dan menguntungkan sehingga produktivitas yang efektif dan efisien dapat tercapai.

Sebaliknya ada juga faktor penghambat kegiatan pengabdian kepada masyarakat. Faktor penghambat ini adalah kesibukan peserta dan pelatih. Peserta pelatihan sibuk dengan kegiatan rutinnya yang umumnya masih berstatus mahasiswa sehingga cukup sulit mencari waktu yang tepat.

\section{KESIMPULAN DAN SARAN}

\section{Kesimpulan}

Kesimpulan dari kegiatan Pengabdian Kepada Masyarakat " Aplikasi Teknologi Tepat Guna Pemisah Kulit Ari Kedelai Untuk Industri Rumahan Pengolahan Tempe" adalah:

1. Kualitas produksi tempe menjadi lebih baik dikarenakan kedelai menjadi lebih bersih

2. Efisiensi waktu dalam membersihkan kedelai menjadi lebih cepat dengan penggunaan alat pemisah kulit ari kedelai

Saran

Saran dalam pelaksanaan kegiatan pengabdian kepada masyarakat adalah perlu adanya kegiatan lanjutan kepada mitra terkait pemeliharaan mesin agar mesin pemisah kulit ari dapat terus digunakan secara maksimal.

\section{UCAPAN TERIMA KASIH}

Ucapan terimakasih kepada semua pihak yang mendukung kegiatan pengabdian kepada masyarakat dapat berjalan lancar. Kegiatan pengabdian kepada masyarakat dibiayai dengan Dana BOPTN yang dikelola oleh Universitas Mataram dan kerjasama dari mitra di Desa Sukamulia.

\section{DAFTAR PUSTAKA}

Andaluri, L., Munir, A.P., Panggabean, S., 2015. Modifikasi Alat Pengupas Kulit Ari Kedelai Dengan Blower. Jurnal Rekayasa Pangan dan Pertanian. Vol 3. No. 3: 389395.

Annas, M. S., 2002. Perancangan Mesin Pengupas Kulit Ari Kacang Kedelai. Universitas Trisakti, Jakarta

Lutfi, M., Ahmad F., Gatot S., dan Abdul F., 2010. Modifikasi dan uji kinerja orbapas (alat pengupas biji kedelai). Balai Penelitian Tanaman Tembakau dan Serat, Malang.Vol. 11 